\title{
USO E COBERTURA DO SOLO DA LAGOA DO BACURI - MA
}

\author{
Kadja Régia Silva Lima ${ }^{(a)}$, Débora Barbosa. Silva ${ }^{(b)}$, Jonas J. Mendes ${ }^{(c)}$, Jorge Hamilton S. dos \\ Santos $^{(\mathrm{d})}$
}

(a) Universidade Estadual do Maranhão - UEMA, E-mail: kadjaregia80@ gmail.com

(b) Universidade Estadual do Maranhão - UEMA, E-mail: deborabarbosa 01@ hotmail.com

(c) Universidade Estadual do Maranhão - UEMA, E-mail: jjonasjansenn@ @otmail.com

(d) Depto. Geografia, UFMA/UFRJ, E-mail: notlimah21@bol.com.br

Eixo: Uso e ocupação das terras e legislação ambiental

\begin{abstract}
Resumo
O artigo faz um estudo espaço-temporal na Lagoa do Bacuri, situada nos municípios de São Bernardo e Magalhães de Almeida, localizada no Leste Maranhense. Objetiva analisar as transformações ocorridas nos anos de 2000, 2009 e 2016, em virtude do uso e ocupação do solo dentro dos parâmetros legais, tendo em vista fornecer subsídios para gestão e fiscalização adequada por parte dos órgãos competentes dos dois municípios já citados. Com o intuito de alcançar o objetivo exposto, estão sendo adotados os seguintes procedimentos metodológicos: Delimitação da lagoa, utilizando imagens Shurttler Radar Topographic Mission (SRTM/2014); Elaboração da carta de uso e cobertura do solo em um raio de $5 \mathrm{~km}$ nos anos de 2000, 2009 e 2016 com utilização de imagens de satélite Landsat 5/TM (219/062) e Landsat 8/OLI (219/062) na escala 1:75.000, utilizando técnicas de geoprocessamento através de SIG e visita in loco. Evidenciando assim, profundas alterações e degradações na paisagem.
\end{abstract}

Palavras chave: Legislação ambiental; Uso e cobertura do solo; Lagoa do Bacuri; Leste maranhense.

\section{Introdução}

A água permeia e determina a vida humana desde os primórdios. Uma vez, que ela foi recurso preponderante para determinar áreas de povoamento, quando a sociedade tornasse sedentária. Cidades inteiras foram construídas considerando a localização e disponibilidade de água potável pura.

De acordo com Tundisi (1999), alterações na quantidade, distribuição e qualidade dos recursos hídricos ameaçam a sobrevivência humana e as demais espécies do planeta, estando o desenvolvimento econômico e social dos países fundamentados na disponibilidade de água de boa qualidade e na capacidade de sua conservação e proteção.

Para Guerra (2006), as mudanças ambientais devidas às atividades humanas sempre aconteceram, mas, atualmente, as taxas dessas mudanças são cada vez maiores, e a capacidade dos humanos em modificar as paisagens também tem aumentado bastante.

Segundo Sopper (1975), nas bacias com cobertura de floresta natural, a vegetação promove a proteção 


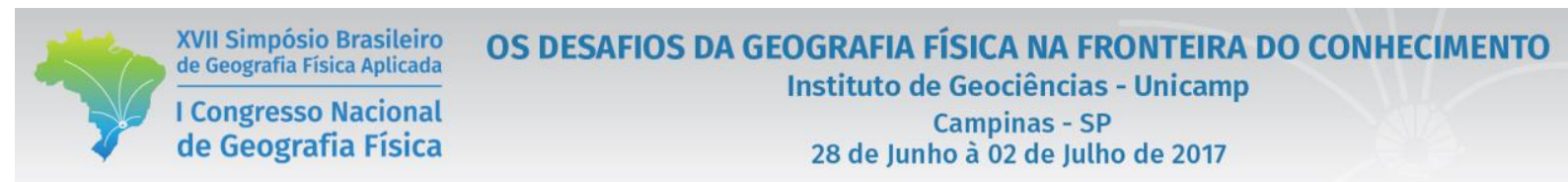

contra a erosão do solo, a sedimentação e a lixiviação excessiva de nutrientes. Fato este, que não difere da realidade encontrada na bacia do rio Buriti.

Diante disso, o estudo objetiva analisar os aspectos paisagisticos do entorno da Lagoa do Bacuri, localizada no Leste Maranhense abrangendo os municípios de São Bernardo e Magalhães de Almeida, bem como elaborar o mapa de análise espaço-temporal do uso e cobertura do solo dos anos 2000, 2009 e 2016 da Lagoa do Bacuri.

\section{Materiais e Métodos}

\subsection{Localização}

A lagoa do Bacuri está localizada na porção leste do Estado do Maranhão, nos municípios de São

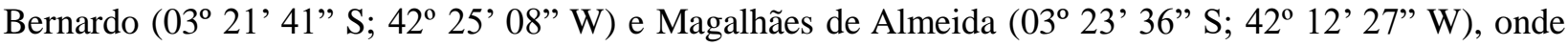
ambos fazem parte da Mesorregião Leste Maranhense e da Microrregião do Baixo Parnaíba Maranhense (Figura 1).

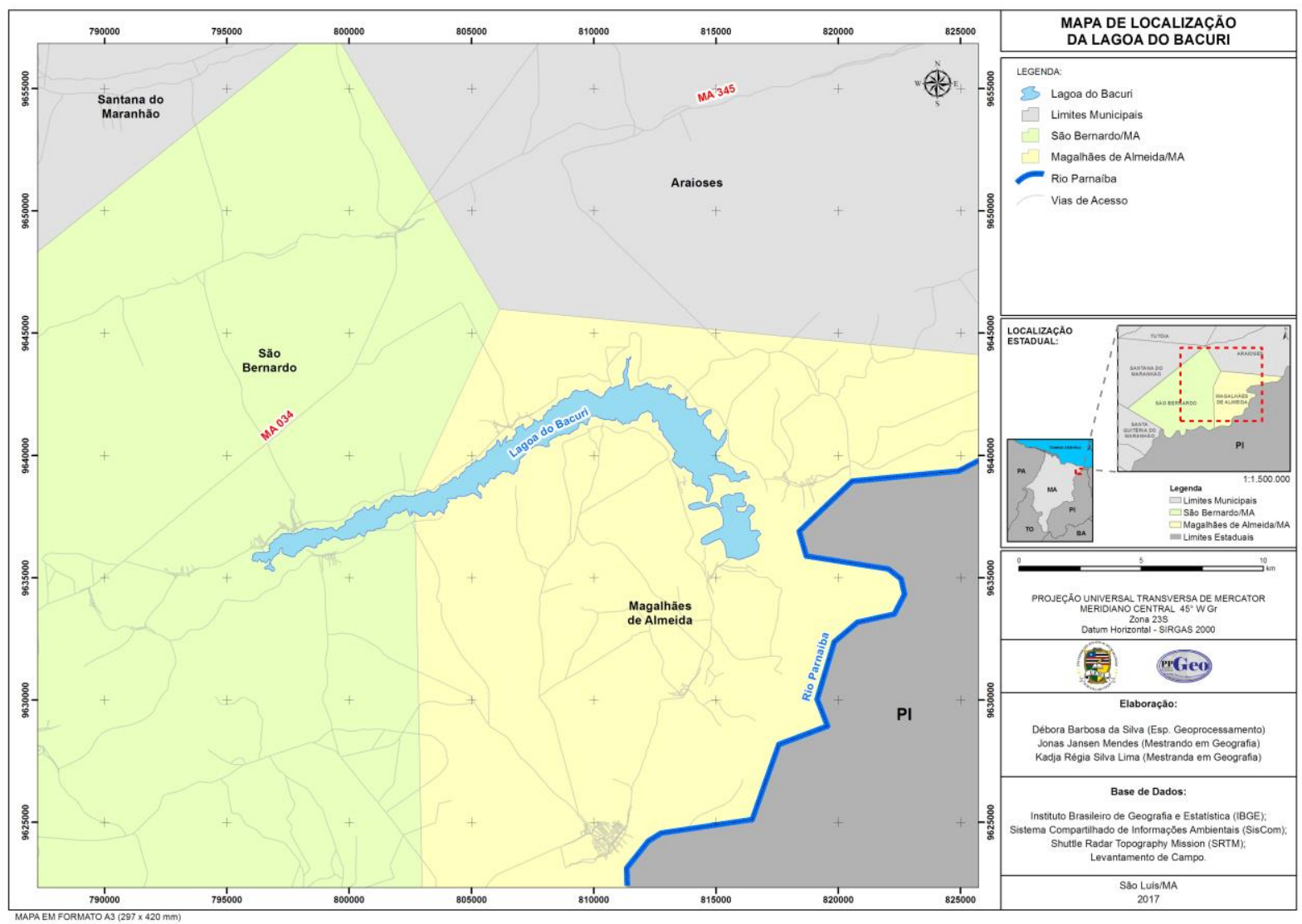

Figura 1 - Localização da área de estudo 
É neste contexto que se encontra a área em estudo, embora tenha sua nascente fora da microrregião supramencionada, o rio Buriti dá origem a Lagoa do Bacuri, localizada nos municípios de São Bernardo e Magalhães de Almeida. Conforme Almeida Júnior (2012), a Lagoa do Bacuri inicia-se no município de São Bernardo, com um perímetro de 63,52 km e uma área de 26,46 km², tendo $23,75 \mathrm{~km}$ de comprimento, e medindo 2,48 km no ponto de maior largura. Vale mencionar ainda que, o Leste maranhense, ampliando para o baixo Parnaíba, teve seus critérios de ocupação baseados em aspectos históricos e circunstanciais.

A delimitação da Lagoa do Bacuri foi realizada através de imagens Shuttle Radar Topography MissionSRTM (2014), onde foi possível extrair, através do Sistema de Informações Geográficas - SIG, a hidrografia que compõe a Lagoa do Bacuri. Também foram utilizados arquivos vetoriais do Sistema Compartilhado de Informações Ambientais - SisCOM para obtenção da hidrografia.

Para a elaboração do mapa de uso e cobertura do solo dos anos de 2000, 2009 e 2016, fez-se um recorte espacial no entorno da área de estudo através de um buffer de cinco quilômetros, sendo este gerado a partir da delimitação da Lagoa do Bacuri feita anteriormente. A classificação do uso e cobertura do solo foi realizada no software ArcGIS 10.2.2 (ESRI) versão trial, através da classificação não supervisionada (Iso Cluster Unsupervised Classification) das imagens Landsat 5/TM (219/062) - 09/06/2000; Landsat 5/TM (219/062) - 05/08/2009; e Landsat 8/OLI (219/062) - 07/07/2016, onde foram criadas três categorias de uso e cobertura, sendo elas: vegetação, solo exposto/uso antrópico e lâmina d'água.

A partir dos dados obtidos através da classificação do uso e cobertura do solo de 2016, foi possível definir as áreas vegetadas e com uso atual dentro das Áreas de Preservação Permanente - APP.

A fundamentação teórico-metodológica está embasada no geossistema, o qual tem o objetivo de analisar e descrever "as partes de um todo", referente à reserva hídrica da lagoa do Bacuri através das análises dos aspectos físicos (geologia, geomorfologia, clima, solos, vegetação, entre outros) e socioambiental.

Em Bertrand (1972), é o valor da visão holística da paisagem (síntese), contrapondo-se à análise compartimentada, que é comumente encontrada na Geografia. Ou seja, sem a combinação de informações obtidas acerca de uma área especifica, os procedimentos e seus consequentes perdem toda a sua significância. Assim, o geossistema que Bertrand, define teoricamente como o resultado da combinação de um potencial ecológico (geomorfologia, clima, hidrologia), uma exploração biológica (vegetação, solo, fauna) e uma ação antrópica, conforme esquema da a seguir:

A abordagem da bacia hidrográfica do rio Buriti, considerando a paisagem da lagoa do Bacuri leva-nos a produzir um referencial teórico-metodológico importante para a gestão de recursos hídricos a partir do 
conjunto de elementos (bióticos, abióticos, antrópicos), em uma multiplicidade de fatores, dentro de uma abordagem integradora.

\subsection{Características fisiográficas da lagoa do Bacuri}

O relevo do Maranhão no qual os municípios de São Bernardo e Magalhães estão inseridos podem ser encontrados os relevos tabulares desdobradas, de forma complexa, em diferentes cotas altimétricas, alçadas por processo diferencial de soerguimento tectônico pós cretácico da Bacia Sedimentar do Parnaíba e delineadas por ação de diferentes eventos de aplainamento regional (BARBOSA et al., 1973; ROSS, 2006).

Geologicamente, com base em dados da CPRM (2013), os municípios em destaque são representados pelos sedimentos da Bacia Sedimentar do Parnaíba, representada pelos Grupo Barreira (ENb) - Terciário; Depósitos Eólicos Continentais (Q1e) e os Depósitos Aluvionares (Q2a) - Quaternário.

Para Feitosa e Trovão (2006), o município de Magalhães de Almeida está inserido em três domínios geoambientais, a saber: Domínio dos Tabuleiros do Nordeste do Maranhão; Domínio de Áreas Dissecadas do Médio e Baixo Parnaíba e Aluviões do Baixo Parnaíba.

No projeto Radam Brasil é classificada em unidades fitogeológicas, a Lagoa do Bacuri, e limita ao norte por savana estépica e ao sul definida como área de tensão ecológica. Marcado pela transição do clima úmido para o semiárido, com predomínio do clima úmido. Sendo marcada pela tensão de savana com floresta estacionária.

A Savana (cerrado) apresenta então uma florística predominantemente amazônica, adaptada através do tempo aos Latossolos alumínicos e mesmo aos Neossolos Quartzarênicos, pela migração de espécies xeromórficas florestais que iam se modificando fenotipicamente de acordo com os novos ambientes lixiviados, os quais condicionaram plantas oligotróficas, ora aquíticas, ora de baixa altura, entre 2 e $10 \mathrm{~m}$ (CPRM, 2013).

De fundamental importância, é o estudo do clima para a compreensão dos processos e modelamento das formas superficiais. Para Moreira e Pires Neto (1998), os estudos do clima permitem identificar a intensidade dos processos que atuam na superfície terrestre, assim como a sua distribuição no espaço, sendo que a velocidade de alteração das rochas ou intemperismo, por exemplo, é fortemente condicionada pela temperatura e precipitação, que neste caso, apresentam temperaturas anuais entre $25-26,5^{\circ} \mathrm{C}$ e precipitações entre $1400-1600 \mathrm{~mm}$. 
Nos estudos pedológicos duas formações são predominantemente características os Plintossolos e Latossolo.

Segundo o IBGE (2015) na área em análise há presença de Plintossolos, os quais se caracterizam principalmente pela presença de expressiva plintitização com ou sem petroplintita (concreções de ferro ou cangas). Os Plintossolos Pétricos geralmente de melhor drenagem, predominam nessa na área em estudo. Estes solos caracterizam-se pela presença no perfil dos horizontes diagnósticos concrecionário e/ou litoplíntico. Em geral, são utilizados apenas para pastoreio extensivo quando sob vegetação campestre ou de Campo Cerrado, ou com pasto plantado com espécies forrageiras rústicas.

Para o IBGE (2015) também são encontrados os Latossolos que em geral, são solos muito intemperizados, profundos e de boa drenagem. Caracterizam-se por grande homogeneidade de características ao longo do perfil, mineralogia da fração argila predominantemente caulinítica ou caulinítica-oxídica, que se reflete em valores de relação Ki baixos, inferiores a 2,2, e praticamente ausência de minerais primários de fácil intemperização. Os Latossolos Amarelos predominam nessa área. Esses solos são profundos, de coloração amarelada, muito homogêneos, boa drenagem e baixa fertilidade natural em sua maioria.

Conceitualmente trata-se no sulco de uma reserva hídrica, por onde correm as águas fluviais, com margens definidas e sua geomorfologia específica, em decorrência de sua descarga, carga sedimentar, declividade, rugosidade, velocidade da água e características litológicas (CHRISTOFOLETTI, 1981).

Evidenciando no exposto acima que o rio Buriti é um dos afluentes que desemboca na margem direita do rio Parnaíba. Ao longo de seu curso o rio transporta sedimentos que acabam por se depositar no curso baixo. A leitura de mapeamento possibilita o entendimento da configuração atual da lagoa a partir do barramento do rio Buriti em sua conexão com o rio Parnaíba por processos naturais.

A lagoa do Bacuri é uma Lagoa conectada, conexão feita por canais de planície. Corpos de água mistos com água freática, pluvial e das cheias. Em determinadas épocas constitui ambiente semiótico.

Além dos rios Buriti e Parnaíba, a lagoa do Bacuri recebe água de pequenos cursos que deságuam ao longo de suas margens na forma de brejos e banhados característicos da região. Como a dinâmica hídrica não é tão intensa surgem plantas aquáticas. Em outros locais, a declividade favorece o surgimento de pequenos córregos perenes.

\section{Resultados e Discussão}

Os impactos das atividades humanas no ciclo hidrológico e na qualidade das águas decorrem de um grande conjunto de atividades humanas, resultados dos usos múltiplos. Ocasionando assim os tensores 
naturais e antrópicos.

SANTOS, MELO e SOUZA (2015) denominam Tensores antropogênicos, como tensores que podem modificar a estrutura físico-química dos ecossistemas alterando também os processos ecológicos, responsáveis pela manutenção dos sistemas naturais e diferentemente dos processos naturais estes ocorrem de maneira acelerada.

\subsection{Tensores socioambientais no uso e cobertura do solo da Lagoa do Bacuri}

A lagoa do Bacuri, que tem sua paisagem modificada e determinada pela a ação conjunta de tensores ambientais, tensores esses que ao longo dos últimos anos vem gerando impactos às unidades de paisagem. $\mathrm{Na}$ área em estudo foram identificadas alterações em maiores e menores proporções no decorrer dos anos em estudo: 2000, 2009 e 2016. Foram observadas variações significativas com relação ao percentual de vegetação e a lâmina d'água, além do crescimento das áreas com solo exposto e com uso antrópico nos últimos anos, decorrente dos seguintes tensores: desmatamentos, pecuária extensiva e agricultura.

$\mathrm{Na}$ análise espaço-temporal do mapa de uso e cobertura do solo (Figura 2), pode-se constatar extensas área de supressão vegetal nos anos de 2000, 2009 e 2016. Em 2000, é perceptível diversas áreas com solos exposto, especialmente no entorno da lagoa, porém, em 2009 houve um significativo avanço da vegetação sobre essas áreas. Apesar disso, em 2016 pode-se constatar áreas consideráveis sem vegetação. 

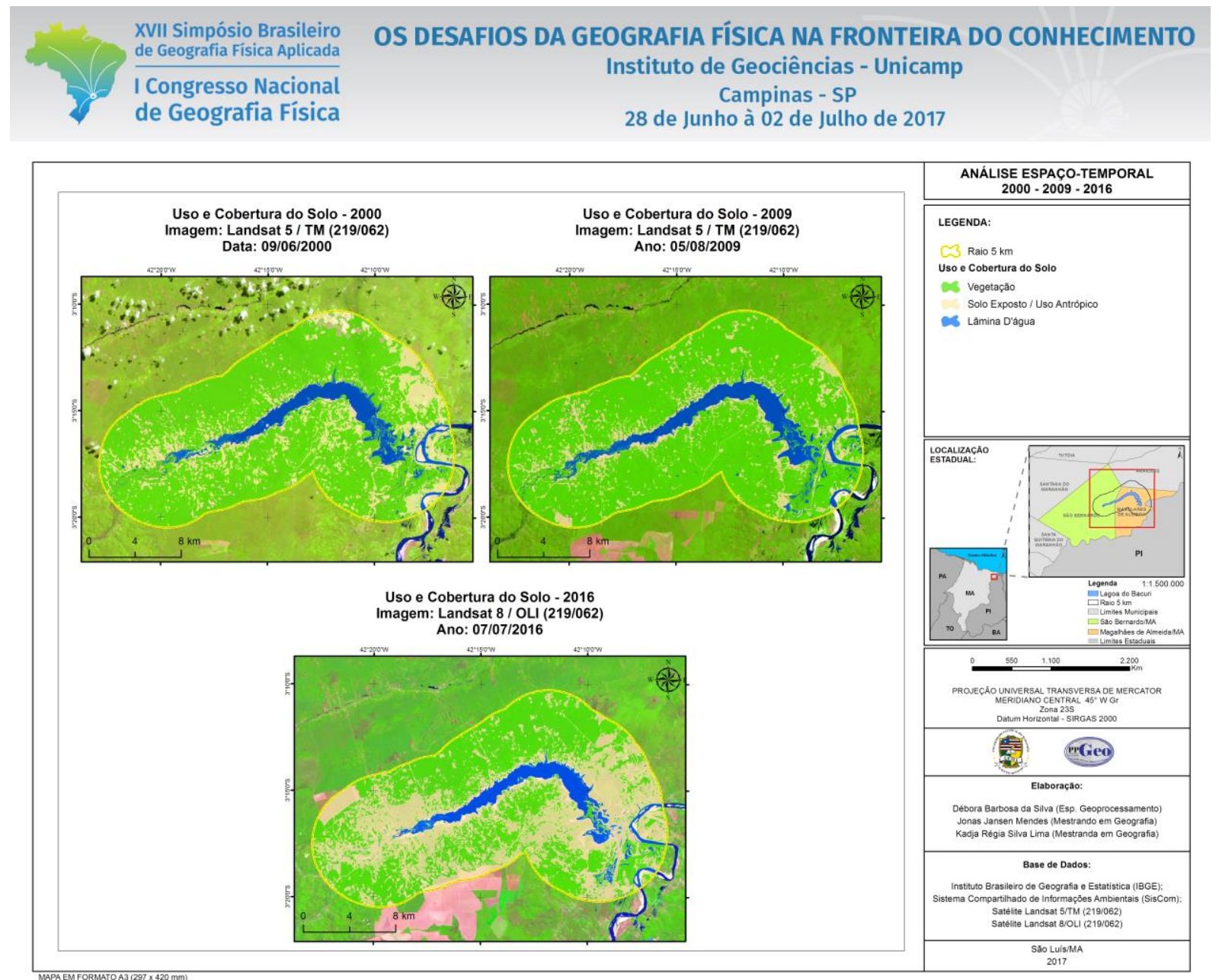

Figura 2 - Mapa da análise espaço-temporal do uso e cobertura do solo (2000, 2009 e 2016)

Seguindo o avanço temporal de monitoramento, chama a atenção no ano de 2009 a redução nas áreas destacadas anteriormente como da ação antrópica, havendo um avanço da vegetação sobre o solo exposto. Ocasionando assim, a uma reposição natural da vegetação de $21,82 \mathrm{~km}^{2}$, o equivalente a $8,18 \%$ de aumento de vegetação em relação a 2000. Conquanto, no ano de 2016, advém uma redução de 116,04 $\mathrm{km}^{2}$, o equivalente a 59,82\% da vegetação em relação a 2009 (Tabela 1).

Estas alterações podem estar associadas ou não à dinâmica climática nos referidos anos, assim como a aprovação do Novo Código Florestal.

Tabela I - Uso e Cobertura do Solo na Lagoa do Bacuri nos anos 2000, 2009 e 2016

\begin{tabular}{cccc}
\hline Uso e Cobertura do Solo & \multicolumn{3}{c}{ Anos } \\
& $\mathbf{2 0 0 0}$ & $\mathbf{2 0 0 9}$ & $\mathbf{2 0 1 6}$ \\
\hline Vegetação & 267,01 & 288,83 & 172,79 \\
Solo Exposto / Uso Antrópico & 86,53 & 60,06 & 185,67 \\
Lâmina D'água & 33,92 & 38,57 & 29,00 \\
\hline
\end{tabular}




\subsection{Influência Climática}

Nesse caso, a dinâmica climática e por conseguinte, os índices pluviométricos podem interferir no avanço da cobertura vegetal. De acordo com dados do PROCLIMA ${ }^{1}$ (2017) e do INPE, em 2000 e 2009 houve índices pluviométricos consideráveis.

A área em estudo teve ocorrência em média de 0-10 dias sem ocorrência de chuva nos anos de 2000 mantendo essa regularidade no mesmo semestre de 2009. Porém, nesse mesmo período, no ano de 2015 ocorreu uma alteração na quantidade de chuvas nessa região, apresentando em média 80 a 90 dias sem precipitações (Figura 3). Esse fato, pode ter influenciado nos resultados obtidos no mapa de uso e cobertura do solo de 2016.
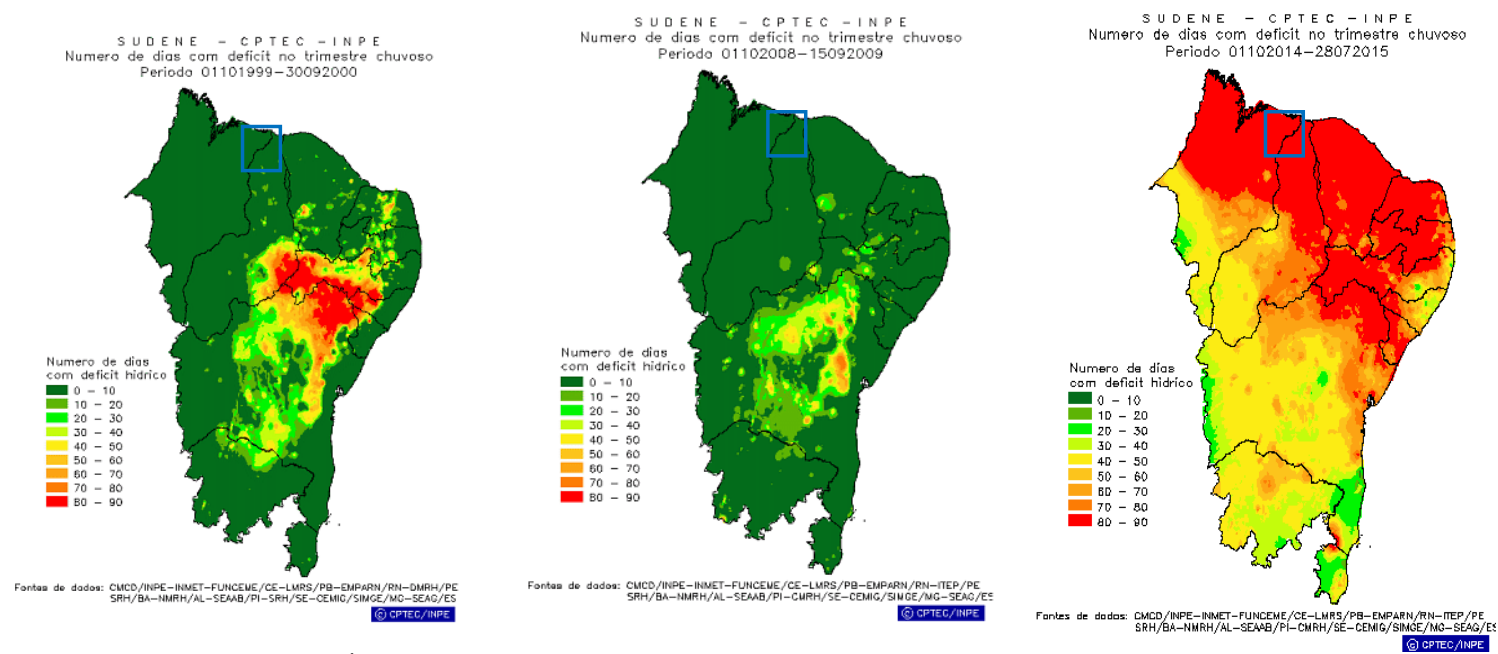

Figura 3 - Índices pluviométricos no Nordeste nos anos de 2000, 2009 e 2015.

Fonte: PROCLIMA, 2017

Segundo dados de INPE e INMET (2017), a área do Leste Maranhense, em especial a Lagoa em estudo, no ano de 2010 possuía um acúmulo de precipitação de $800 \mathrm{~mm}$ variando entre os meses de outubro/2009 a setembro de 2010 e obteve um acúmulo 300 mm em São Bernardo e 200mm em Magalhães de Almeida, onde encontra-se mais de $90 \%$ da Lagoa. Contudo no ano de 2015 ocorreu uma anomalia de precipitação

${ }^{1}$ O PROCLIMA, Programa de Monitoramento Climático em Tempo Real da Região Nordeste, é uma iniciativa conjunta da Sudene_e do Ministério da Integração Nacional, para monitorar a estação chuvosa na Região Nordeste. O Proclima é executado pelo INPE/CPTEC e pelos Estados da Região Nordeste, Minas Gerais e Espírito Santo, através dos núcleos e laboratórios estaduais participantes do PMTCRH - Programa de Monitoramento de Tempo, Clima e Recursos Hídricos. 
(anomalias são os dados com 5\% acima ou abaixo da média da série temporal, podendo ser positiva ou negativa). Desta forma, tem-se uma anomalia negativa, comparando aos dados, já citados anteriormente, dos anos 2000 e 2009.

\subsection{Projeto "Tabuleiros de São Bernardo"}

Outra hipótese levantada para explicar as alterações de vegetação nos anos elencados é com relação ao projeto de irrigação "Tabuleiros de São Bernardo" em Magalhães de Almeida. Este projeto foi instalado no ano 1980 com o objetivo de gerar produção de fruticultura irrigada, tirar famílias da pobreza e combater a seca.

Segundo MARANHÃO (2017) o projeto Perímetro Irrigado “Tabuleiros de São Bernardo" é vinculado ao Ministério da Integração Nacional, por meio do Departamento Nacional de Obras Contra as Secas (Dnocs), vinculado ao Ministério da Integração Nacional, e está praticamente abandonado.

O projeto possuía uma área irrigável de 11 mil hectares para ser utilizado, mas somente 541 hectares foram entregues pelo Dnocs e destes apenas 327 hectares foram utilizados para a produção de frutas como banana, melancia, coco, limão, tangerina, laranja, mamão, goiaba e caju.

O projeto "Os Tabuleiros de São Bernardo", tinha como objetivo solucionar o problema da seca para os moradores locais, porém este passou a contribuir com o desmatamento da mata nativa local, visualizado no mapa de uso e ocupação do ano de 2000 no entorno da lagoa do Bacuri, especificamente no povoado de Trincheiras a nordeste da lagoa.

Desde o ano 2000 o projeto está desativado, o que explica a regeneração da cobertura vegetal mostrada no período entre o ano de 2000 e 2009, visto que, a ausência da produção agrícola na área somada aos altos índices pluviométricos levou a este fato.

\subsection{Legislação Ambiental - O Novo Código Florestal}

Com relação ao Código Florestal (BRASIL, 2012), o mesmo estabelece critérios legais para o uso e ocupação das Áreas de Preservação Permanente, conforme o Art. $7^{\circ}$ :

Art. $7^{\circ} \mathrm{A}$ vegetação situada em Área de Preservação Permanente deverá ser mantida pelo proprietário da área, possuidor ou ocupante a qualquer título, pessoa física ou jurídica, de direito público ou privado.

$\S 1^{\circ}$ Tendo ocorrido supressão de vegetação situada em Área de Preservação Permanente, o proprietário da área, possuidor ou ocupante a qualquer título é obrigado a promover a 


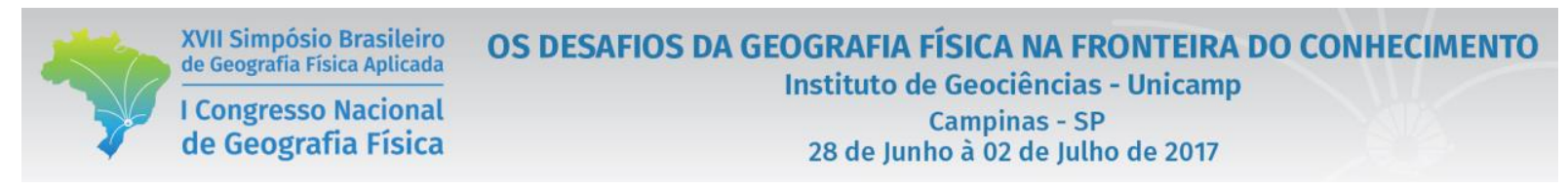

recomposição da vegetação, ressalvados os usos autorizados previstos nesta Lei.

A diminuição da cobertura vegetal nas Áreas de Preservação Permanente entre o ano de 2009 e 2016 pode ser justificada pelo Artigo 62-B, tendo em vista que a legislação permite que áreas suprimidas antes de 22 de julho de 2008 não sejam recuperadas integralmente. Todavia, áreas suprimidas após esta data deveram ser recuperadas suas matas nativas em sua totalidade.

No caso de supressão em Área de Preservação Permanente não autorizada até 22 de julho de 2008, o Código Florestal (BRASIL, 2012) diz:

Art. 61-A. Nas Áreas de Preservação Permanente, é autorizada, exclusivamente, a continuidade das atividades agrossilvipastoris, de ecoturismo e de turismo rural em áreas rurais consolidadas até 22 de julho de 2008.

[...]

$\S 6^{0}$ Para os imóveis rurais que possuam áreas consolidadas em Áreas de Preservação Permanente no entorno de lagos e lagoas naturais, será admitida a manutenção de atividades agrossilvipastoris, de ecoturismo ou de turismo rural, sendo obrigatória a recomposição de faixa marginal com largura mínima de:

I - 5 (cinco) metros, para imóveis rurais com área de até 1 (um) módulo fiscal;

II - 8 (oito) metros, para imóveis rurais com área superior a 1 (um) módulo fiscal e de até 2 (dois) módulos fiscais;

III - 15 (quinze) metros, para imóveis rurais com área superior a 2 (dois) módulos fiscais e de até 4 (quatro) módulos fiscais; e

IV - 30 (trinta) metros, para imóveis rurais com área superior a 4 (quatro) módulos fiscais.

$[\ldots]$

Art. 61-B. Aos proprietários e possuidores dos imóveis rurais que, em 22 de julho de 2008, detinham até 10 (dez) módulos fiscais e desenvolviam atividades agrossilvipastoris nas áreas consolidadas em Áreas de Preservação Permanente é garantido que a exigência de recomposição, nos termos desta Lei, somadas todas as Áreas de Preservação Permanente do imóvel, não ultrapassará:

I - 10\% (dez por cento) da área total do imóvel, para imóveis rurais com área de até 2 (dois) módulos fiscais;

II - 20\% (vinte por cento) da área total do imóvel, para imóveis rurais com área superior a 2 (dois) e de até 4 (quatro) módulos fiscais;

A legislação oferece ao proprietário a possibilidade de produção dentro de uma APP, considerada uma área frágil, de risco ambiental e com uma função de conservação ambiental. Portanto, a produção em uso consolidado de APP requer um planejamento estabelecido considerando o que estabelece a legislação ambiental.

A partir das questões anteriormente discutidas com relação a ocupação antrópica nas Área de Preservação Permanente, tem-se a seguir o a Figura 4 apresentando a situação atual das APPs no 


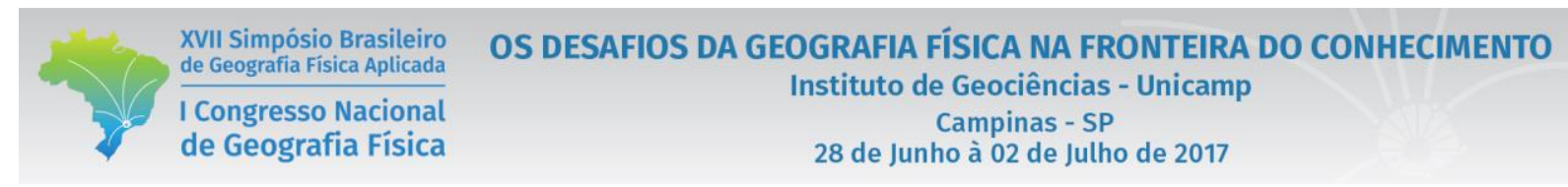

entorno da Lagoa do Bacuri.

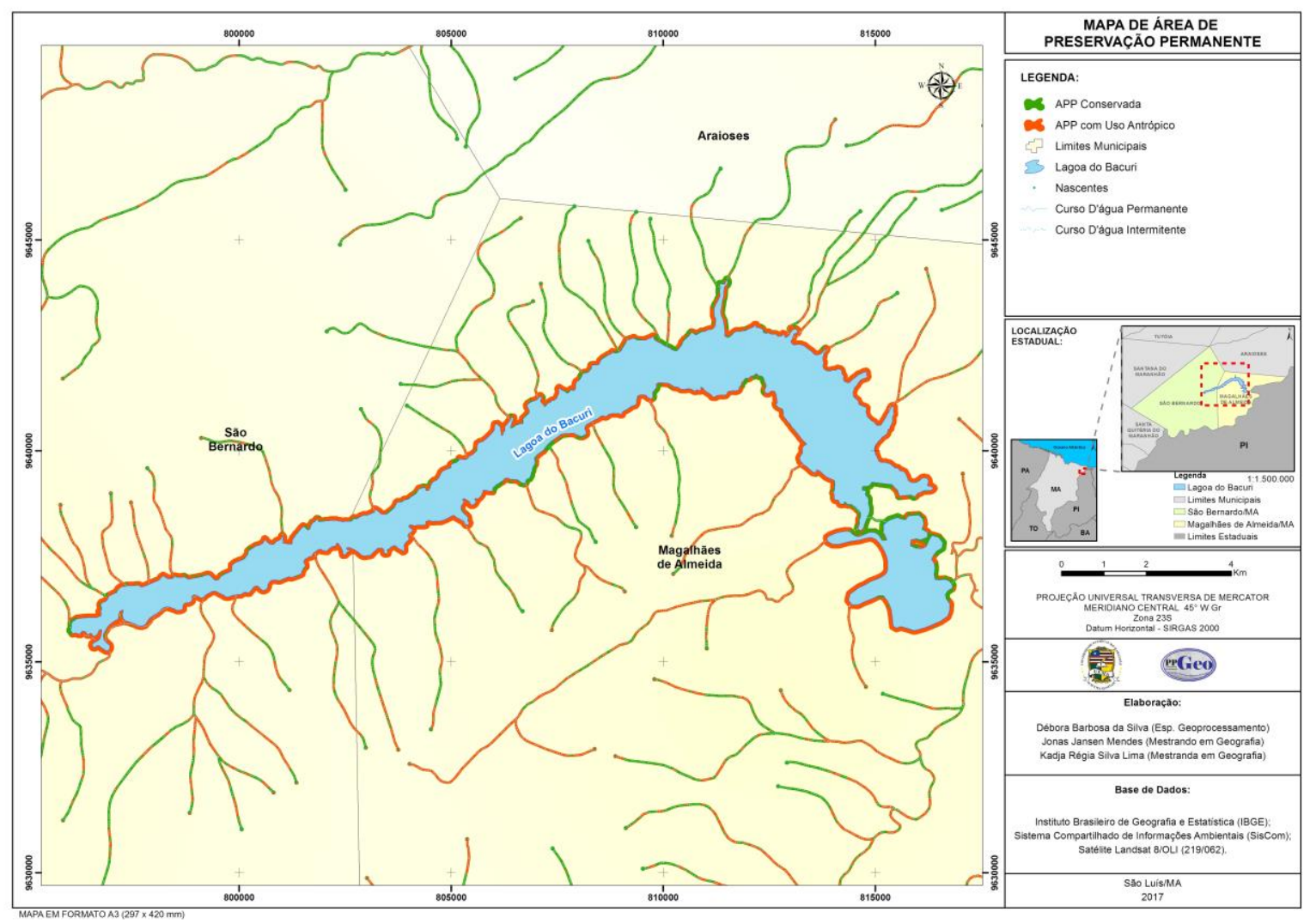

Figura 4 - Mapa de Área de Preservação Permanente com áreas conservadas e em uso no ano de 2016

\section{Conclusões}

Este trabalho vem suscitar e subsidiar o debate sobre os tensores que vem favorecendo as transformações e a reconstrução da paisagem no entorno da lagoa do Bacuri.

Destacou-se o desmatamento, tendo como agentes principais a pecuária e a agricultura, porém períodos longos de seca também contribuíram para inibir o crescimento da vegetação. Além disso, a pesca predatória, a silvicultura (eucalipto) e a criação extensiva de gado (suíno, bovino, equinos e asininos) que pastoreiam as margens da lagoa, degradando solos e provocando erosão e contaminação das águas e de espécies exóticas de peixes, também são tensores ambientais que contribuem para diminuição da cobertura vegetal da Bacia do Bacuri.

A busca do crescimento econômico e social passa indiscutivelmente pela boa gestão das águas. Toda atividades econômicas destacadas não se desenvolvem sem a participação desse recurso natural considerado patrimônio mundial e bem de uso comum. 


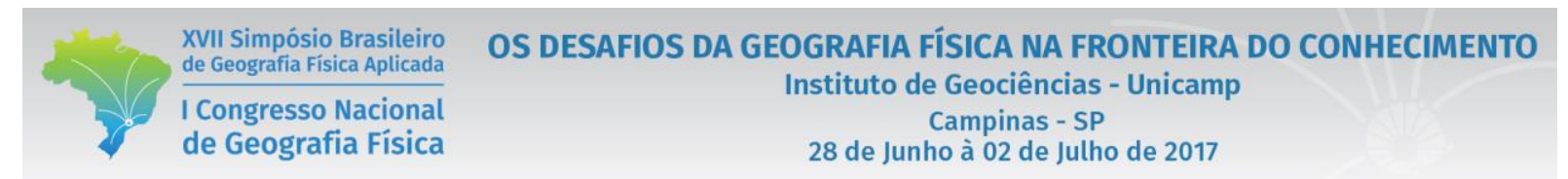

Propõe-se assim, uma fiscalização e monitoramento por meio de gestão conjunta entre os dois municípios aos quais a lagoa do Bacuri pertence e abastece. Na tentativa de reduzir os danos ambientais e as possíveis contaminações no corpo hídrico, em detrimento do crescimento econômico.

\section{Bibliografia}

BERTRAND, G. Paisagem e geografia física global. Esboço Metodológico. Caderno de Ciências da Terra. São Paulo, n. 13, p. 1-27,1972

BRASIL. Código Florestal. Lei $\mathbf{n}^{\mathbf{0}} \mathbf{1 2 . 6 5 1}$, de 25 de maio de 2012. Disponivel em: < http://www.planalto.gov.br/ccivil_03/_ato2011-2014/2012/lei/112651.htm>. Acesso em: 08 de janeiro de 2017.

CHRISTOFOLLETTI, A. Análise de Sistemas em Geografia. São Paulo: HUCITEC

Ciências da Terra. São Paulo, n. 13, p. 1-27,1972

CPRM - Serviço geológico do Brasil. Geodiversidade do estado do Maranhão. [Org.]: Iris Celeste Nascimento. Teresina : CPRM, 2013.

GUERRA, Antonio Teixeira e GUERRA, Antonio José Teixeira. Dicionário geológico-geomorfológico. Rio de Janeiro: Bertrand Brasil, 1997.

IBGE. Instituto Brasileiro de Geografia e Estatística. Geociências. Manual técnico de pedologia / IBGE, Coordenação de Recursos Naturais e Estudos Ambientais. - 3. ed. - Rio de Janeiro : IBGE, 2015. 316 p. - : il. (Manuais técnicos em geociências, ISSN 0103-9598; n. 4).

JÚNIOR, Edivan Silva Almeida. Lagoa do Bacuri, Magalhães De Almeida - Ma: Interrelações das Comunidades do Entorno com o Ecossistema sob a ótica da Sustentabilidade. 2012.In:sigaa.ufma.br .acesso: 24/06/2015

MARANHÃO. Governo busca revitalizar o projeto 'Tabuleiros de São Bernardo' na região do Baixo Parnaíba. Disponível em: < http://www.ma.gov.br/governo-busca-revitalizar-o-projeto-tabuleiros-de-sao-bernardona-regiao-do-baixo-parnaiba>. Acesso em: 09 de janeiro de 2017.

MOREIRA, C. V. R.; PIRES NETO, A. G. Clima e Relevo. In: OLIVEIRA, A. M. S.; BRITO, S. N. A. Geologia de Engenharia. São Paulo: Associação Brasileira de Geologia de Engenharia, 1998.

ROSS, J. Ecogeografia do Brasil: subsídios para planejamento ambiental. São Paulo: Oficina deTextos, 2006.

SANTOS, S. S. C.; MELO e SOUZA, R. (2015) Caracterização dos principais tensores antropogênicos nas áreas de manguezal do litoral sul de Sergipe. In: GOUVEIA, L. (Org.). Saberes multidisciplinares. $1^{\circ}$ ed. Salvador: Mundo Acadêmico, v.6, pp. 142-158.

TUNDIDI, J.G \& TUNDISI, T. M. Potencial impact of changes in the Forest Law in relation to water resources. Biota Neotrop.10(4): http://www.biotaneotropica.org.br/v10n4/en/abstract?article+bn01110042010. Acesso em 20.12.2016. 